\title{
BRANDING IN THE ACTIVITIES OF EUROPEAN OF NATIONAL TOURISM ORGANIZATIONS (NTO)
}

\author{
MIROSŁAW MARCZAK
}

Koszalin University of Technology, POLAND

e-mail:miromilan@wp.pl

KEYWORDS | branding, brand, branded products, national tourism organizations, promotion

ABSTRACT An analysis of the selected aspects of activities taken within the framework of branding by European national tourism organizations (NTO) is the main purpose of the article. The branding activities of 39 national organizations that function on the territory of Europe were the subject of the analysis. In particular, theoretical deliberations concerning understanding of branding in the national and foreign literature of the subject were presented in the study. The main criteria were characterized based on which national tourism organizations were selected for the research. The selected aspects of the practical use of branding by the NTO examined (including the scope of activities taken within the framework of branding, perception and identification of branding by the organizations examined with various issues, the use of branded products in promotional campaigns) were all presented. In the study, a research hypothesis was accepted, namely that branding plays an essential role in the activities of the present-day national tourism organizations, and its rank and scope of use is constantly increasing. Because of this, it is becoming one of the key activities undertaken by the organizations of this type.

\section{Introduction}

Although the notion of branding has been functioning for a relatively short period now in the literature of the subject, branding has been fairly recognized as a very effective way to obtain a possibly improvement of quality, and to increase the rank and effectiveness of the selected tourist sectors. Within the last two decades, branding has become a very important element to shape 
a marketing approach consisting in the cooperation of many heterogenic stakeholders who should cooperate to achieve the desirable result (Green, 2005).

The term of "branding" is very often identified with the brand, which is not legitimate. This is a certain narrowing of a notion which does not present the entire process of the creation and impact of the brand. The creation of a brand on the market should not be considered merely as actions that are limited to names and symbols. It requires the use of many functional and tool strategies, whereas properly understood branding is in reality a synonym of marketing but with respect to the brand.

An analysis of the selected activities taken within the framework of branding by 39 European national tourism organizations (NTO) is the main purpose of the article. In the study, a research hypothesis was accepted namely that branding plays an important role in the activities of the presentday national tourism organizations; its rank and scope of use is constantly increasing. Because of this, it is becoming one of the key activities undertaken by the organizations of this type.

\section{Notion of branding in the literature}

Due to the interdisciplinary and multifaceted nature of branding, and its real effectiveness and market efficiency, numerous authors took up this issue (including Aaker 1991, 1997, 2002; Anholt 2002, 2003a, 2003b, 2005, 2006, 2007, 2009, 2010; Anholt, Spaven 2009; Ashworth 2010, Boyle 2003; Cliffton, Simmons 2004; de Chernatony, McDonald 2003; Dinnie 2008; Fan 2006; Gabrielsson 2005; Govers 2009; Govers, Go 2009; Kavaratzis, Ashworth 2006; Majewski 2000, 2007, 2012; Marczak 2012, 2013a, 2013b; Morgan 2004; Pike 2002, 2004a, 2004b, 2008, 2009; Pike, Page 2014; Richie, Richie 1998; Tesławski 2013; Żemła 2009, 2012). It should also be emphasized that interest in this issue may follow from the fact that branding possesses a universal nature. It can be used both in relation to an enterprise and a tourist destination (e.g. a region or a country) and its tourist products. However, in the latter case, there is a widespread belief that first a given tourist destination should possess a product(s) so that one could commence building brand awareness. In national and foreign literature that deals with the subject, branding is defined various ways (Table 1).

The review presented of the definitions of branding emphasizes the multifaceted nature of this notion and its widespread use in the brand building process. Regardless of the differences in the definition of the notion of branding which are indicated by the authors referred to above, a number of problems connected with this issue can be observed. It becomes evident that e.g. in tourist economy the notion of branding is not synonymous. C. Blain, S.E. Levy and J.R.B. Ritchie (2005) are among those who have carried out studies in this area with a group of 409 DMOs - Destination Management Organization (chiefly from the United States and Canada). The results obtained explicitly demonstrate that the term of branding is interpreted in various ways by decision-makers. The most frequent formulations and key words provided in connection with this notion include the following: image (33.3\%), recognition/identification (21.1\%), differentiation $(17.7 \%)$, cohesion (15.5\%), communication (14.4\%), guests' emotions (11.1\%), creation of expectations $(11.1 \%)$. 
Table 1. Definition of branding according to different authors and sources

\begin{tabular}{|c|c|c|}
\hline No. & Author (authors, source) & Definition \\
\hline 1. & S. Anholt & $\begin{array}{l}\text { Process or procedure of designing, planning and communication of the name and the } \\
\text { region's identity to build and/or manage its reputation }\end{array}$ \\
\hline 2. & $\begin{array}{l}\text { A. Czubała, A. Jonas, } \\
\text { T. Smoleń, J.W. Wiktor }\end{array}$ & $\begin{array}{l}\text { Name, notion, sign, symbol, figure, melody or a combination of these elements created } \\
\text { to denote the service (product) and making it distinctive from those by competitors }\end{array}$ \\
\hline 3. & K. Dinnie, M. Fola & It is perceived as a means for the diversification of brands in the eyes of target customers \\
\hline 4. & M. Hereźniak & The process of representation and conscious collection of values that make up reputation \\
\hline 5. & J. Kall & $\begin{array}{l}\text { Active and consistent presentation of advantages that distinguish a given brand, its prod- } \\
\text { ucts and services from competitive ones }\end{array}$ \\
\hline 6. & M. Łuczak & $\begin{array}{l}\text { The process of designing, planning, building and communication of the brand: its identity, } \\
\text { name, symbolism or value: to build reputation and the image }\end{array}$ \\
\hline 7. & P. Kotler, D. Gartner & $\begin{array}{l}\text { It may be treated as a "serious tool to create the diversity of products" and a "representa- } \\
\text { tion of the promise of value from the customer's perspective" }\end{array}$ \\
\hline 8. & M. Mazurek & $\begin{array}{l}\text { It comprises a set of marketing activities aimed at the creation of an appropriate name, } \\
\text { symbol, logo and graphic sign }\end{array}$ \\
\hline 9. & S. Pike & $\begin{array}{l}\text { It is perceived as the core of marketing, the core of marketing strategies and aiming at in- } \\
\text { creasing the brand's value in the awareness and the minds of customers }\end{array}$ \\
\hline 10. & A. Rausch & $\begin{array}{l}\text { Within the framework of branding, three levels of activities are distinguished, i.e. creative, } \\
\text { managerial and communication }\end{array}$ \\
\hline 11. & S. Saraniemi, M. Ahonen & $\begin{array}{l}\text { The connection of the perception of the brand on the market by customers with "unique } \\
\text { selling proposition" (USP) that characterize a given brand }\end{array}$ \\
\hline 12. & $\begin{array}{l}\text { World Tourism Organization, } \\
\text { European Travel Commission }\end{array}$ & It constitutes the "DNA" of every tourist destination \\
\hline
\end{tabular}

Source: author's own study based on: Anholt (2007); Czubała, Jonas, Smoleń, Wiktor (2012); Dinnie, Fola (2009); Kall (2001); Kotler, Gartner (2002); Łuczak (2010); Mazurek (2008); Nyvoll Antonsen (2010); Pike (2004); Rausch (2009); Saraniemi (2008).

However, the research carried out with 43 members of European Travel Commission (ETC) and by the World Tourism Organization in the year 2008 demonstrated that the notion branding is first of all associated with a set of values (18\%), with the competition of identity (17\%), with the idea of the area of tourist reception (17\%), with the image (13\%), with the logo $(9 \%)$, with the product (7\%), with stylistics (7\%), with sound (6\%) and with the marketing campaign $(6 \%)$ - Handbook... (2009).

\section{Selection of national tourism oryanizations to be included in the research}

The main criteria which were taken into consideration in the selection of national tourism organizations to be included in the research are as follows:

- the functional criterion: the main functions attributed to national tourism organizations were accepted as the basis for verification: in the first order, attention was paid as to whether the promotion of a given country on foreign markets is included in these tasks,

- the economic criterion: possession of an autonomous financial budget (regardless of the percentage share of funds from the state budget, private sector or other sources) by a given NTO was accepted as the basis for verification, 
- the organizational criterion: distinguishing of a given NTO in the organization structure of the institution it is directly subordinate to (e.g. a ministry or another government institution that supervises a given NTO) was accepted as the basis for verification.

For the purpose of the verification of the number of those NTO institutions that take the abovementioned criteria into considering, the main assumption was accepted, namely that it is only those entities which meet at least one of these criteria are accepted in the research, whereas in such a case, this criterion must be the realization of tasks by a given NTO in the area of the widely understood promotion of a given country on foreign markets. This activity should be included in the statute (or another official document) of this organization. It should also be emphasized that a failure to meet the remaining criteria by individual NTO entities does not mean that these organizations do not possess their budgets or that they do not function within the framework of specified organizational structures. The reason for this may be difficulties connected with obtaining official and credible information on this matter.

It was demonstrated based on the accepted criteria that there are 46 typical NTO entities that operate on the central (national) level and realize the chief objectives that are assigned to this type organizations (including promotion of a given country on foreign markets) currently function in Europe. 39 organizations ( $84.7 \%$ of population) were finally covered by the analysis, cf. Table 2 .

Table 2. National tourism organizations qualified for the research according to the accepted criteria

\begin{tabular}{|c|c|c|c|c|c|}
\hline No. & Country & Name of NTO & $\begin{array}{c}\text { Implementation } \\
\text { of statutory tasks } \\
\text { in the area of the promotion } \\
\text { of the country } \\
\text { on foreign markets }\end{array}$ & $\begin{array}{c}\text { Possession } \\
\text { of autonomous } \\
\text { budget }\end{array}$ & $\begin{array}{c}\text { Distinguishing } \\
\text { of a superior entity } \\
\text { in the organizational } \\
\text { structure }\end{array}$ \\
\hline 1 & 2 & 3 & 4 & 5 & 6 \\
\hline 1. & England & Visit England & + & + & + \\
\hline 2. & Austria & Österreich Werbung & + & + & + \\
\hline 3. & Belgium & Visit Flanders & + & + & + \\
\hline 4. & $\begin{array}{l}\text { Bosnia } \\
\text { and Herzegovina }\end{array}$ & Tourism Association of FB\&H & + & - & - \\
\hline 5. & Croatia & $\begin{array}{l}\text { Croatian National } \\
\text { Tourist Board (CNTB) }\end{array}$ & + & + & + \\
\hline 6. & Cyprus ${ }^{*}$ & $\begin{array}{l}\text { Cyprus Tourism Organization } \\
(\mathrm{CTO})\end{array}$ & + & + & + \\
\hline 7. & Montenegro & $\begin{array}{l}\text { National Tourism } \\
\text { Organisation of Montenegro }\end{array}$ & + & + & - \\
\hline 8. & Czech Republic & CzechTourism & + & + & + \\
\hline 9. & Denmark & Dansk Turistrad & + & + & + \\
\hline 10. & Estonia & Enterprise Estonia & + & + & + \\
\hline 11. & Finland & $\begin{array}{l}\text { Finland Tourist Board (MEK), } \\
\text { Visit Finland }\end{array}$ & + & + & + \\
\hline 12. & France & Atout France & + & + & + \\
\hline 13. & Greece & $\begin{array}{l}\text { Greek National } \\
\text { Tourism Organization (GNTO) }\end{array}$ & + & + & + \\
\hline 14. & Spain & TURESPANA & + & + & + \\
\hline 15. & The Netherlands & Holland Marketing (NBTC) & + & + & + \\
\hline
\end{tabular}




\begin{tabular}{|c|c|c|c|c|c|}
\hline 1 & 2 & 3 & 4 & 5 & 6 \\
\hline 16. & Ireland + North Ireland & Tourism Ireland & + & + & + \\
\hline 17. & Ireland & Failte Ireland & + & + & + \\
\hline 18. & North Ireland & $\begin{array}{l}\text { Norther Ireland } \\
\text { Tourist Board (NITB ) }\end{array}$ & + & + & + \\
\hline 19. & Island & $\begin{array}{l}\text { Visit Iceland, Promote } \\
\text { Iceland }\end{array}$ & + & + & + \\
\hline 20. & Liechtenstein & Lichtenstein Marketing & + & - & - \\
\hline 21. & Luxembourg & $\begin{array}{l}\text { Luxembourg National } \\
\text { Tourism Organization }\end{array}$ & + & + & - \\
\hline 22. & Latvia & $\begin{array}{l}\text { Latvia Tourism } \\
\text { Development Agency (LTDA) }\end{array}$ & + & + & + \\
\hline 23. & Malta & $\begin{array}{l}\text { Malta Tourism Authority } \\
\text { (MTA) }\end{array}$ & + & + & + \\
\hline 24. & Monaco & $\begin{array}{l}\text { Department of Tourism and } \\
\text { Conferences (DTC) }\end{array}$ & + & - & - \\
\hline 25. & Germany & $\begin{array}{l}\text { Deutsche Zentrale für } \\
\text { Tourismus (DZT) }\end{array}$ & + & + & + \\
\hline 26. & Norway & Innovation Norway & + & + & + \\
\hline 27. & Poland & $\begin{array}{l}\text { Polska Organizacja } \\
\text { Turystyczna (POT) }\end{array}$ & + & + & + \\
\hline 28. & Portugal & Turismo de Portugal & + & + & + \\
\hline 29. & Romania & Romania Tourism & + & + & - \\
\hline 30. & Serbia & $\begin{array}{l}\text { Serbia National Tourism } \\
\text { Organization }\end{array}$ & + & + & - \\
\hline 31. & Slovakia & Slovak Tourist Board (STB) & + & + & + \\
\hline 32. & Slovenia & SPIRIT Slovenia & + & + & + \\
\hline 33. & Scotland & Visit Scotland & + & + & + \\
\hline 34. & Sweden & Visit Sweden & + & + & + \\
\hline 35. & Switzerland & Switzerland Tourism & + & + & + \\
\hline 36. & Wales & Visit Wales & + & + & + \\
\hline 37. & Hungary & $\begin{array}{l}\text { Hungary National } \\
\text { Tourism Organization } \\
\text { (HNTO) }\end{array}$ & + & + & + \\
\hline 38. & Great Britain (whole) & Visit Britain & + & + & + \\
\hline 39. & Italy & $\begin{array}{l}\text { Italian Government Tourist } \\
\text { Board (ENIT) }\end{array}$ & + & + & + \\
\hline
\end{tabular}

Explanations: ", - Cyprus was taken into consideration in the analysis in spite of the fact that this country is commonly considered as an Asian country. Nevertheless, for many years now, it has been conducting large-scale activities for the promotion of European tourism while being among others a member of the European Travel Commission (ETC); "+" - the element occurs; "-" - the element does not occur or no reliable information on this topic was found.

Source: author's own study based on the Annual Report and ... (2011); Annual Report... (2013, 2014); Annual Report... (2012); Annual Report... (2011); Annual Report... (2010); Annual Tourism Report... (2013); Annual Report 2013/2014... (2014); Informe... (2015); OECD Tourism... (2010, 2012, 2014); UNWTO Annual... (2014).

\section{Selected aspects of the use of branding by the NTO entities examined}

The analysis carried out demonstrated that among the NTO entities examined, a vast majority (92.3\%) use branding in practice, whereas it is only $7.7 \%$ of the organizations analyzed that do not take any activities in this area (Figure 1). 


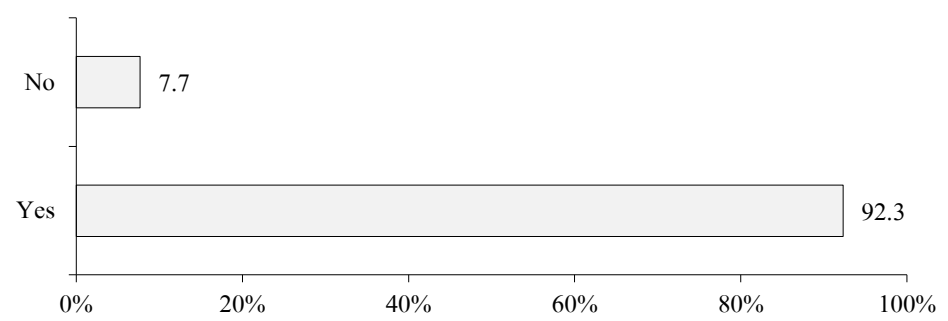

Figure 1. Use of branding by the national tourism organizations examined Source: author's own research.

The analysis carried out also permitted the author to define the geographical range of the activities taken by European NTO in the area of branding. When analyzing the phenomenon examined, it can be clearly seen that a vast majority of those organizations that operate in Europe (91.7\%) realize branding on the global tourist market, while few of these $(8.3 \%)$ limit their activities in this area to the continent only (Figure 2).

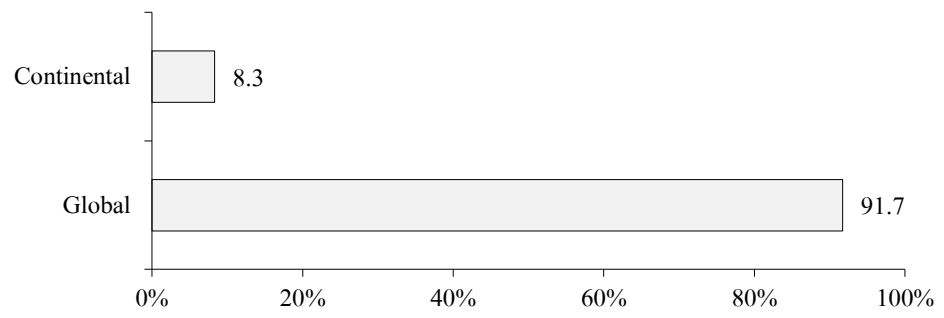

Figure 2. Range of activities within the framework of branding which are taken by NTO entities examined Source: author's own research.

The results of studies (including those by Blain, Levy, Ritchie 2005; ETC, 2013), presented in the first subsection, demonstrated that the notion of branding is not unambiguous. Branding is quite frequently identified with various issues (including the image, identification, distinguishing, a specific set of values, competition of the identity of the tourism reception area, the idea of the tourism reception area etc.). The analysis carried out by the author demonstrated that for European NTO entities, branding constitutes first of all the image (50\% of indications), it reveals differences between competitive tourism reception areas (27.8\%), is an identification of the tourism reception area and visual elements (25\% of indications each) as well as the understanding of the tourism reception area and the promises fulfilled by a given tourism reception area $(22.2 \%$ of indications each); cf. Figure 3. 


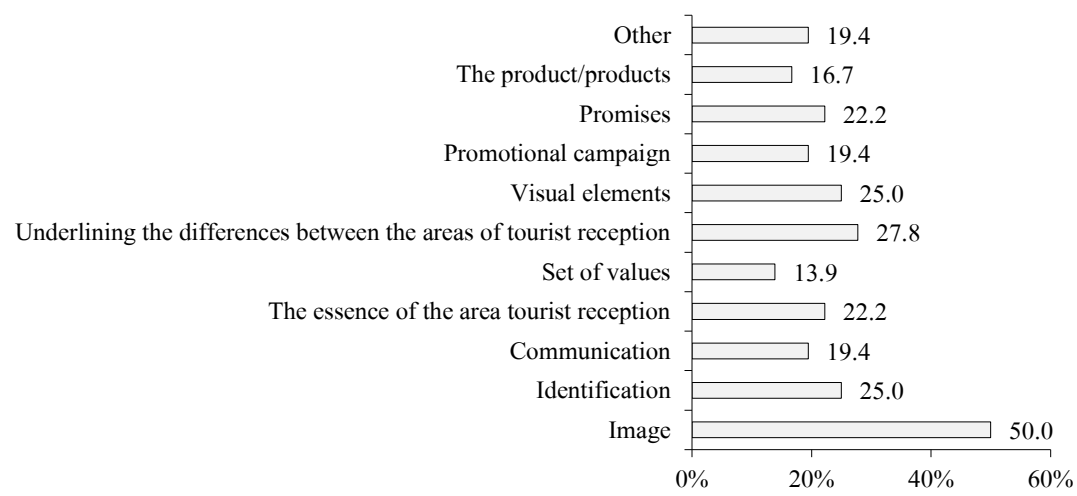

Figule 3. Identification of branding with other issues by NTO entities examined

Source: author's own research.

The use of various branded products in promotional campaigns is one of the main aspects of the realization of branding by the NTO examined (Figure 4). Such branded products as: natural values $(60.5 \%)$, various events $(55.3 \%)$, individual types of tourism (39.5\%), culture, monuments and regions (34.2\% of indications each).

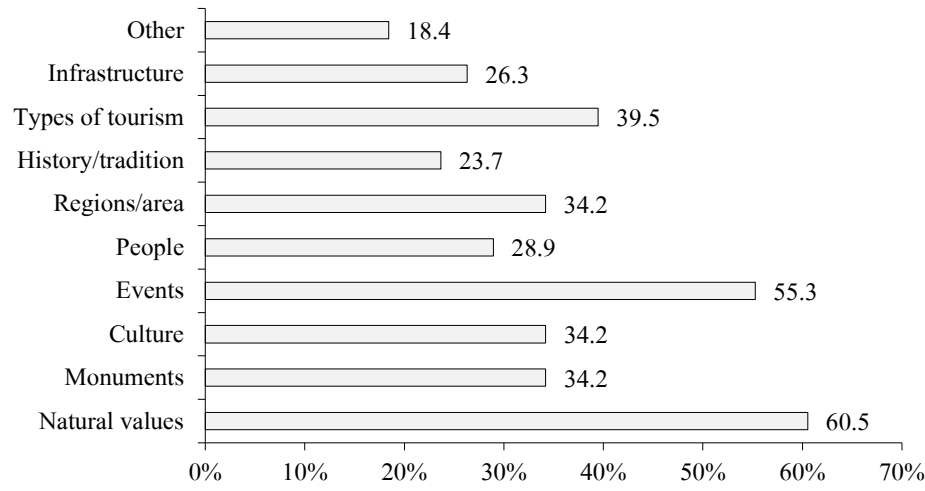

Figure 4. Types of branded products used by the NTO examined in promotional campaigns

Source: author's own research.

The analysis carried out demonstrated that branded products very often constitute the core of promotional campaigns realized. However, their natures and impact ranges differ. The structure of these products is also quite diversified. The examples of the use of specific branded products by national tourism organizations are presented in Table 3. 
Table 3. Examples of branded products used in the promotional campaigns of selected NTO entities

\begin{tabular}{|c|c|c|c|}
\hline No. & Country & Name of NTO & Promotional campaign that make use of branded products \\
\hline 1 & 2 & 3 & 4 \\
\hline 1. & Austria & $\begin{array}{l}\text { Österreich } \\
\text { Werbung }\end{array}$ & $\begin{array}{l}\text { Brand: "Vacation in Austria": Austria is presented as a unique country in three aspects, } \\
\text { i.e.: } \\
\text { - a blend of tradition and modernity that forms a unique relation (mainly cultural } \\
\text { diversity) } \\
\text { - Austrian life style (cordiality, pleasant attitude to guests, connoisseurship of tastes) } \\
\text { - varied topography and climatic conditions that are favourable to leisure activities }\end{array}$ \\
\hline 2. & Croatia & $\begin{array}{l}\text { Croatian National Tourist } \\
\text { Board (CNTB) }\end{array}$ & $\begin{array}{l}\text { Promotion of tourist products based on the following leading motives: sun and sea, } \\
\text { maritime tourism, health tourism, culture tourism: including UNESCO heritage, busi- } \\
\text { ness tourism, sports tourism: including golf, cycling tourism, ecotourism, mountain } \\
\text { tourism, qualified tourism, event tourism: including festivals }\end{array}$ \\
\hline 3. & Cyprus & $\begin{array}{l}\text { Cyprus Tourism } \\
\text { Organization (CTO) }\end{array}$ & $\begin{array}{l}\text { - Promotional campaigns that use the following types of products: ferry voyages, } \\
\text { qualified tourism, windsurfing, sailing, diving, recreational tourism, agritourism, } \\
\text { natural values, pilgrimage tourism, gastronomy, events } \\
\text { - "LoveCyprus" promotional campaign: the year-long island (2007) } \\
\text { - Campaign on the Internet portal: HeartCyprus.com - "HeartCyprus" - jointly } \\
\text { undertaken with the tourist branch and aimed at a virtual presentation of tourist } \\
\text { attractions } \\
\text { - Promotional campaigns realized on individual markets: } \\
\text { - Great Britain: presentation of the possibilities to take up golf on the island } \\
\text { - Ireland: weddings, honeymoons in Cyprus } \\
\text { - Germany: golf } \\
\text { - Switzerland: mountain cycling } \\
\text { - Greece: cultural education }\end{array}$ \\
\hline 4. & $\begin{array}{l}\text { Czech } \\
\text { Republic }\end{array}$ & CzechTourism & $\begin{array}{l}\text { - Marketing activities to raise awareness related to the potential of national tourism } \\
\text { - Tourism and continuation of material cultural heritage } \\
\text { - "Czech Specials": discover the taste of the Czech Republic, campaigns to promote } \\
\text { the Czech cuisine (e.g. year 2002: "Year of the Czech cuisine") }\end{array}$ \\
\hline 5. & France & Atout France & $\begin{array}{l}\text { Promotional campaigns that use branded products such as e.g.: Castles of the Loire, the } \\
\text { Eiffel Tower, the Louvre, the French Riviera, the French Alps }\end{array}$ \\
\hline 6. & Spain & TURESPAÑA & $\begin{array}{l}\text { - Zear 1998: "Bravo Spain" campaign: increasing the competitiveness of Spain on the } \\
\text { international tourist market } \\
\text { - "Visit Spain, visit Madrid": a campaign using the brand of the "Real Madrid" Club } \\
\text { and its footballers to promote the country and its capital city }\end{array}$ \\
\hline 7. & Ireland & Failte Ireland & $\begin{array}{l}\text { - Leading products include the following: leisure tourism in individual counties, city } \\
\text { tourism, cultural tourism: festivals, castles, galleries, cuisine natural values: includ- } \\
\text { ing gardens, national parks, sights of nature } \\
\text { - } \text { the USP (the Unique Selling Proposition) for the promotional activities of Ireland is } \\
\text { based on three values, i.e.: friendly people, wet weather, GMO free cuisine } \\
\text { - Campaigns realized: } \\
\text { - year 2013: "Derry-Londonderry" - "Town of Culture" } \\
\text { - year 2013: "The Gathering Ireland": including a mobile app: "collection of ges- } \\
\text { tures", studies of family histories } \\
\text { - year 2013: "Jump into Ireland": realized in two dimensions, i.e. for young people: } \\
\text { "socially energizing..." and for elderly people: "culturally curious..." } \\
\text { - year 2012: "Titanic's Year": a number of events connected with the "Titanic" } \\
\text { - year 2011: "House of Champions": use of the tourist potential after the success } \\
\text { of the leading golfer, i.e. R. McIlroy }\end{array}$ \\
\hline
\end{tabular}




\begin{tabular}{|c|c|c|c|}
\hline 1 & 2 & 3 & 4 \\
\hline 8. & Germany & $\begin{array}{l}\text { Deutsche Zentrale } \\
\text { für Tourismus (DZT) }\end{array}$ & $\begin{array}{l}\text { Two main lines of products: } \\
\text { - tourism in towns: culture, events } \\
\text { - leisure tourism } \\
\text { They are introduced with the use of the so-called topics of the year, e.g.: } \\
\text { - year 2000: "Listen and experience Bach" } \\
\text { - year 2008: castles, parks and gardens } \\
\text { - 2009: "Active Vacation in Germany": life style, hikes and cycling trips" } \\
\text { - year 2010: "European Capital City of Culture - Ruhr.2010, Cities of culture in } \\
\text { Germany" } \\
\text { - year 2011: Health vacation in wellness \&spa in Germany" }\end{array}$ \\
\hline 9. & Poland & $\begin{array}{l}\text { Polska Organizacja } \\
\text { Turystyczna (POT) }\end{array}$ & $\begin{array}{l}\text { - Year 2010: marketing campaign: "Let's Promote Poland Together": including a voy- } \\
\text { age of the "Fryderyk Chopin" sailing ship to European seaports, e.g. in Sweden, } \\
\text { Denmark, Germany, the Netherlands, Belgium, France and Great Britain. This } \\
\text { campaign was realized under the working title: "Chopin the Course - Sea of Offers" } \\
\text { - Year 2010: national marketing campaign: "Beautiful East - Discover How Close } \\
\text { It Is" entitled "The Beautiful East" using a number of branded tourist products that } \\
\text { function in eastern Poland } \\
\text { - 2011-2012: activities promoting the EURO } 2012 \text { organization in Poland }\end{array}$ \\
\hline 10. & Portugal & Turismo de Portugal & $\begin{array}{l}\text { - Promotional campaigns based on the leading products, i.e.: sun and sea, health and } \\
\text { looks, leisure in cities, landscape of culture (including UNESCO heritage, events) } \\
\text { cuisine, ecotourism, natural values, golf fields, maritime tourism, business tourism. } \\
\text { - Promotional campaign "Life in Portugal: aimed at encouraging foreigners to reside } \\
\text { in this country }\end{array}$ \\
\hline 11. & Serbia & $\begin{array}{l}\text { Serbia National Tourism } \\
\text { Organization }\end{array}$ & $\begin{array}{l}\text { - Marketing campaign „Active on the Danube”: depiction of the Danube as all- } \\
\text { European tourist product, depiction of the natural, cultural and historical variety of } \\
\text { the Region of the Danube } \\
\text { - Presentations of Serbia in many cities in Germany (for the representatives of tourist } \\
\text { industry) }\end{array}$ \\
\hline 12. & Slovenia & SPIRIT Slovenia & $\begin{array}{l}\text { Leading products in promotional campaigns: nature (including caves, forests, climate, } \\
\text { varied lie of the land), numerous health-resorts, variety of wine, culinary and ethno- } \\
\text { logical culture of the country, possibility to go in for various forms of tourism }\end{array}$ \\
\hline 13. & Italy & $\begin{array}{l}\text { Italian Government } \\
\text { Tourist Board (ENIT) }\end{array}$ & $\begin{array}{l}\text { - Leading products in promotional campaigns: history, culture and arts, faith and } \\
\text { religion, nature: richness of natural values, city tourism } \\
\text { - Campaigns realized: } \\
\text { - 2012-2013: "Cultural tourism for visually disabled people” } \\
\text { - year 2013: „Year of Faith” }\end{array}$ \\
\hline
\end{tabular}

Source: author's own study based on www.atout-france.fr; www.austriatourism.com; www.croatia.hr; www.czechtourism.cz; www.failteireland.ie; www.germany-tourism.de; www.italia.it; www.pot.gov.pl; www.serbia.travel; www.spiritslovenia. si; www.tourspain.es; www.turismodeportugal.pt; www.visitcyprus.com.

Such branded products as: tradition, culture, history, folk customs, cuisine, natural values, anthropogenic values (monuments), elements of tourist infrastructure, various events (concerts, festivals, sports events), individual types of tourism or widely understood environment-friendly actions are most frequently used as the objects of promotion.

\section{Conclusions}

The present article covers selected aspects of the use of branding by European national tourism organizations. It was demonstrated among others that branding constitutes one of the most important areas of the activities of modern national tourism organizations (NTO). Undoubtedly, it 
is one of key elements for competition between tourist destinations. However, it should be clearly emphasized that this is a long-term and multi-dimensional process, one which involves a number of aspects related to the functioning of the present-day areas of tourist reception. Furthermore, it involves the aspects of the functioning of various social groups. As mentioned previously, the brand currently constitutes an extremely essential element of competition between regions while simultaneously being an indicator for tourists of the quality level of services offered in a given area. For this very reason, activities undertaken within the framework of branding are becoming the most important element that remains under the control of those who manage tourist reception areas. It is the activities of national tourist organizations that are of particular importance here. They are responsible for the promotion of national destinations on the international market.

By making references to the research hypothesis accepted in the introduction, it was demonstrated that a vast majority of the European NTO entities examined perceive branding as an essential part of the promotional campaigns realized, while it should be clearly emphasized that branding is very often identified with other issues (including the image, differences between the individual areas of tourist reception, visual elements, promotional campaigns), which is not well justified. Nonetheless, a vast majority of the NTO entities examined (92.3\%) use branding in practice. This is demonstrated by the global range of the activities taken within the framework of branding by $91.7 \%$ of the organizations examined and a wide range of various branded products which are used in promotional campaigns.

To sum up the current deliberations, it should be emphasized that branding constitutes the most important tool in the marketing of tourist reception areas by contributing to an increased competitiveness between destinations. However, it should be clearly emphasized that branding cannot be treated as a remedy for any problems connected with the development and promotion of tourist reception areas. Branding is not able to satisfy everybody. What is more, makes an attempt to do so, the effects are not satisfactory.

\section{References}

Aaker, D.A. (1991). Managing Brand Equity. New York: Simon and Schuster.

Aaker, D.A. (1997). Dimensions of Measuring Brand Personality. Journal of Advertising Research, 34.

Aaker, D.A. (2002). Building Strong Brands. London: Simon and Schuster.

Anholt, S. (2002). Brand New Justice: The Upside of Global Branding. New York: Butterworth-Heinemann Title.

Anholt, S. (2003a). Brand New Justice: How Branding Places and Products Can Help the Developing World. Oxford: Elsevier Butterworth-Heinemann.

Anholt, S. (2003b). Branding Places and Nations, in: Brands and Branding. London: The Economist in association with Profile Books Ltd.

Anholt, S. (2005). Brand America - tajemnica mega marki. Warszawa: Instytut Marki Polskiej.

Anholt, S. (2006). Competitive Identity: The New Brand Management for Nations, Cities and Regions. Londyn: Palgrave Macmillan.

Anholt, S. (2007). Tożsamość konkurencyjna. Nowe spojrzenie na markę. Warszawa: Instytut Marki Polskiej.

Anholt, S. (2009). Places, Identity, Image and Reputation. London: Palgrave Macmillan.

Anholt, S. (2010). Great Brand Stories: Brand America. New York: Marshall Cavendish. 
Anholt, S., Spaven, P. (2009). International Place Brand Yearbook. Basingstoke: Palgrave Macmillan.

Annual Report and Accounts for The Year Ended 31 March 2011. VisitScotland 2011.

Annual Report 2013. European Travel Commission, Brussels-Belgium 2013.

Annual Report 2014. European Travel Commission, Brussels-Belgium 2014.

Annual Report 2013/2014, NITB Annual Report and Accounts for the year ended 31 March 2014. Laid before the Northern Ireland Assembly under Part II Articles 8 and 9 of the Tourism (Northern Ireland) Order 1992, 3 December 2014.

Annual Report 2012. Switzerland Tourism, Zürich 2012.

Annual Report 2010 Fáilte Ireland, Report and Financial Statements for the Year Ended 31 December 2010. To the Minister for Tourism, Culture and Sport, National Tourism Development Authority Act 2003, Dublin 2010.

Annual Report 2011 Fáilte Ireland, Report and Financial Statements For the Year Ended 31 December 2011. To the Minister for Tourism, Culture and Sport, National Tourism Development Authority Act 2003, Dublin 2011.

Annual Tourism Report 2013 Austria, Belgium, Croatia, Cyprus, Czech Republic, Finland, France, Germany, Greece, Hungary, Iceland, Ireland, Italy, Malta, Netherlands, Poland, Romania, Slovakia, Slovenia, Sweden. European Commission 2013.

Ashworth, J.G. (2010). Towards Effective Place Brand Management: Branding European Cities and Regions. London: Edward Elgar Publishing Ltd.

Blain, C., Levy, S.E., Ritchie, J.R.B. (2005). Destination Branding: Insights and Practices from Destination Management Organizations. Journal of Travel Research, 43.

Boyle, D. (2003). Authenticity: Brands, Fakes, Spin and the Lust for Real Life. London: Flamingo.

Cliffton, R., Simmons, J. (2004). Brands and Branding, 1st ed. London: Profile Book Ltd.

Czubała, A., Jonas, A., Smoleń, T., Wiktor, J.W. (2012). Marketing usług. Warszawa: Wolters Kluwer Polska.

de Chernatony, L., McDonald, M. (2003) Creating Powerful Brands, 3rd edition. Oxford: Elsevier, Butterworth Heinemann.

Dinnie, K. (2008). Nation Branding: Concepts, Issues, Practice. Oxford: Butterworth-Heinemann.

Dinnie, K., Fola, M. (2009). Branding Cyprus - a stakeholder identification perspective, Accepted for 7th International Conference on Marketing, Athens Institute for Education and Research (ATINER), Athens, Greece.

ETC (2013). European Tourism in 2013: Trends \& Prospects (Q1/2013). Brussels: European Travel Commission (ETC), May.

Fan, Y. (2006). Branding the nation: What is being branded? Journal of Vacation Marketing, 12.

Gabrielsson, M. (2005). Branding Strategies of Born Globals. Jourmal of International Entreprenuership, 3.

Green, S. (2005). Defining West London - A case study of the initial stages of a strategic place branding exercise. CoDesign, 1 (4).

Govers, R. (2009). From place marketing to place branding and back. Place Branding and Public Diplomacy, 7 (4).

Govers, R., Go, F. (2009). Place Branding: Global, Virtual and Physical Identities, Constructed, Imagined and Experienced. Basingstoke: Palgrave Macmillan.

Handbook on Tourism Destinations Branding, World Tourism Organization (UN WTO), European Travel Commission (ETC) (2009). Madrid, Spain.

Informe Anual 2014 Subdirección General de Estudios, Análisis y Planes de Actuación (2015). Madrid: Ministerio de Industria, Energía y Turismo.

Kall, J. (2001). Silna marka: istota i kreowanie. Warszawa: PWE.

Kavaratzis, M., Ashworth, G. (2006). Place marketing: how did we get here and where are we going? Journal of Place Management and Development, 1 (2).

Kotler, P., Gartner, D. (2002). Country as a brand, product and beyond: A place marketing and brand management perspective. The Journal of Brand Management, $9(4 / 5)$.

Łuczak, M. (2010). Rola identyfikacji wizualnej w kreowaniu marki i aktywizacji obszaru turystycznego. Acta Scientiarum Polonorum Oeconomia, 9 (4).

Majewski, J. (2000). Technika kreowania marki w marketingu turystycznym. In: A. Szwichtenberg, W. Deluga (eds.), Rola marketingu w rozwoju regionów turystycznych. Koszalin: Politechnika Koszalińska. 
Majewski, J. 2007, Struktury organizacyjne dla brandingu produktów terytorialnych, „, Rocznik Naukowy Wyższej Szkoły Turystyki i Rekreacji im. M. Orłowicza w Warszawie”, Tom 6. Warszawa: Wyższa Szkoła Turystyki i Rekreacji im. M. Orłowicza w Warszawie.

Majewski, J. (2012). Branding w zarządzaniu popytem na turystykę wiejską. Ekonomiczne Problemy Ustug, 83.

Marczak, M. (2012). Markowe produkty turystyczne w działaniach promocyjnych wybranych Narodowych Organizacji Turystycznych (NTO). Zeszyty Naukowe Wydziału Nauk Ekonomicznych Politechniki Koszalińskiej, 16.

Marczak, M. (2013a). Branding w turystyce - przykłady wykorzystania przez narodowe organizacje turystyczne w wybranych krajach. In: Gospodarka turystyczna w regionie. Rynek turystyczny - wspótczesne trendy, problemy i perspektywy jego rozwoju. Prace Naukowe Uniwersytetu Ekonomicznego we Wrocławiu nr 304, Wrocław.

Marczak, M. (2013b). Produkty markowe i ich wykorzystanie przez narodowe organizacje turystyczne (NTO) w działaniach na rzecz kreowania wizerunku turystycznego państw. Ekonomiczne Problemy Turystyki, 1 (21).

Mazurek, M. (2008). Tourism Destination Branding: A Competitive Marketing Strategy - Does it really matter? A Case Study of Kremnica, Slovakia. Proceedings of the 4th graduate Student research Symposium, Victoria, BC, Canada.

Morgan, N. et al. (2004). Destination Branding: Creating the Unique Destination Proposition, 2nd edition. Oxford: Elsevier Butterworth-Heinemann.

Nyvoll Antonsen, I.M. (2010). The stakeholders involvement in the process of building and maintaining a destination brand. Oslo: Master in International Management.

OECD Tourism Trends and Policies 2010, 2012, 2014, OECD Publishing.

Pike, S. (2002). Destination Image Analysis - A Review of 142 Papers from 1973 to 2000. Tourism Management, 23 (5).

Pike, S. (2004a). Destination brand positioning slogans - towards the development of a set of accountability criteria. Acta Turistica, 16 (2).

Pike, S. (2004b). Destination Marketing Organizations, An Integrated Marketing Communication Approach. Zagreb: MPuls.

Pike, S. (2008). Destination Marketing An Integrated Marketing Communication Approach. Butterworth-Heinemann is an imprint of Elsevier.

Pike, S. (2009). Destination brand positions of a competitive set of near-home destinations. Tourism Management, 30.

Pike, S., Page, S. (2014). Destination Marketing Organizations and destination marketing: A narrative analysis of the literature. Tourism Management, 41.

Rausch, A. (2009). Capitalizing on Creativity in Rural Areas: National and Local Branding in Japan. Journal of Rural and Community Development, 4 (2).

Richie, J.B., Ritchie, R.J.B. (1998). The Branding of Tourism Destination: Past Achievements and Future Trends. Reports of 48th Congress, AIEST, St-Gall.

Saraniemi, S., Ahonen, M. (2008). Destination Branding from Corporate Branding Perspective. Proceedings of the Conference on Corporate Communication 2008, June 6th-9th, Wroxton, England.

Tesławski, M. (2013). Praktyka brandingu. Lublin: „Słowa i myśli”.

UNWTO Annual Report 2013, World Tourism Organization (UNWTO), Madrid, Spain 2014.

www.atout-france.fr.

www.austriatourism.com.

www.croatia.hr.

www.czechtourism.cz.

www.failteireland.ie.

www.germany-tourism.de.

www.italia.it.

www.pot.gov.pl.

www.serbia.travel.

www.spiritslovenia.si.

www.tourspain.es. 
www.turismodeportugal.pt.

www.visitcyprus.com.

Żemła, M. (2009). Nowe zastosowania marki jako narzędzia w marketingu produktu obszarów recepcji turystycznej. In: Gospodarka turystyczna w regionie Przedsiębiorstwo. Samorząd. wspólpraca. Prace Naukowe Uniwersytetu Ekonomicznego we Wrocławiu nr 50, Wrocław.

Żemła, M. (2012). The idea of destination brand licensing and the question of its effectiveness. Tourism and Hospitality Management, 18 (2).

\section{BRANDING W DZIAŁANIACH EUROPEJSKICH NARODOWYCH ORGANIZACJI TURYSTYCZNYCH (NTO)}

SŁOWA KLUCZOWE

STRESZCZENIE branding, marka, produkty markowe, narodowe organizacje turystyczne, promocja

Głównym celem artykułu jest zaprezentowanie wyników analizy wybranych aspektów działań podejmowanych w ramach brandingu przez europejskie narodowe organizacje turystyczne (NTO). Przeanalizowano działania brandingowe 39 krajowych organizacji funkcjonujących na terenie Europy. W szczególności w opracowaniu przedstawiono teoretyczne rozważania dotyczące pojmowania brandingu w krajowej i zagranicznej literaturze przedmiotu, scharakteryzowano główne kryteria, na podstawie których dobrano narodowe organizacje turystyczne do badań, a także przedstawiono wybrane aspekty praktycznego wykorzystywania brandingu przez badane NTO (m.in. zasięg działań podejmowanych w ramach brandingu, postrzeganie i utożsamianie brandingu przez badane organizacje z różnego rodzaju zagadnieniami, wykorzystywanie produktów markowych w kampaniach promocyjnych). W opracowaniu przyjęto hipotezę badawczą zakładającą, że branding odgrywa istotną rolę w działaniach współczesnych narodowych organizacji turystycznych, a jego ranga i zakres wykorzystywania stale wzrastają, co powoduje, że staje się on jednym z kluczowych działań podejmowanych przez tego typu organizacje. 